\title{
Questions and comments on the efficacy of transforaminal laser annuloplasty versus intradiscal radiofrequency annuloplasty for discogenic low back pain
}

\author{
Daehyun Jo \\ Pain Center, Pohang Wooridul Hospital, Pohang, Korea
}

Received May 8, 2019, Revised May 20, 2019, Accepted May 21, 2019

Correspondence

Daehyun Jo

Pain Center, Pohang Wooridul Hospital, 256 Poseuko-daero, Buk-gu, Pohang 37755, Korea

Tel: +82-54-240-6000, Fax: +82-54-240-6195, E-mail: pandjo@naver.com

\section{LETTER TO THE EDITOR}

I read the article titled 'Efficacy of transforaminal laser annuloplasty versus intradiscal radiofrequency annuloplasty for discogenic low back pain' authored by Park et al. [1]. It is an interesting paper to the interventional pain physician. I would like to point out some issues. As the authors said, there are a lot of treatment modalities for chronic discogenic pain. So, we need appropriate patient selection according to the indications before doing invasive treatments. According to the authors, the inclusion criteria included an annular tear of the disc, and the exclusion criteria included a herniated intervertebral disc $[2,3]$. Did they do discography for all the patients? If not, how did they confirm the annular tear without the herniated disc? It would have been better to show us the evidence of the distinction between an annular tear and a herniated disc.

When the authors did transforaminal epiduroscopic laser annuloplasty (TELA), they removed the disc material using forceps, which means it was a percutaneous endoscopic lumbar discectomy (PELD). Does that mean that they did a PELD with a TELA? We need some endoscopic pictures from the TELA, which would help the readers to understand their procedures. The authors described the intradiscal radiofrequency annuloplasty (IDRA) procedure in Materials and Methods, which said that 'After placement of the cannula, granulation tissue could often be visualized, with spinal scope (LASE, Minneapolis, MN). However, in the discussion on page 118 in the left column, they described their IDRA as being under $\mathrm{C}$ arm fluoroscopy, rather than being performed endoscopically'.

It looks like they used transforaminal laser annuloplasty (TFLA) and TELA for the same procedure. If not, we need to establish their definitions for TFLA and TELA, and correct the overuse of abbreviations, which obstruct and interrupt scientific communication.

\section{CONFLICT OF INTEREST}

No potential conflict of interest relevant to this article was reported.

\section{ORCID}

Daehyun Jo, https://orcid.org/0000-0001-8310-6561 (a) This is an open-access article distributed under the terms of the Creative Commons Attribution Non-Commercial License (http://creativecommons.org/licenses/by-nc/4.0/), which permits unrestricted non-commercial use, distribution, and reproduction in any medium, provided the original work is properly cited.

(c) The Korean Pain Society, 2019
Author contributions: Daehyun Jo: Writing/manuscript preparation. 


\section{REFERENCES}

1. Park CH, Lee KK, Lee SH. Efficacy of transforaminal laser annuloplasty versus intradiscal radiofrequency annuloplasty for discogenic low back pain. Korean J Pain 2019; 32: 113-9.

2. Fardon DF, Milette PC; Combined Task Forces of the North American Spine Society, American Society of Spine Radiology, and American Society of Neuroradiology. Nomenclature and classification of lumbar disc pathology. Recommendations of the Combined task Forces of the North American
Spine Society, American Society of Spine Radiology, and American Society of Neuroradiology. Spine (Phila Pa 1976) 2001; 26: E93-113.

3. Fardon DF, Williams AL, Dohring EJ, Murtagh FR, Gabriel Rothman SL, Sze GK. Lumbar disc nomenclature: version 2.0: Recommendations of the combined task forces of the North American Spine Society, the American Society of Spine Radiology and the American Society of Neuroradiology. Spine J 2014; 14: 2525-45.

\section{Author's reply}

\section{Chan Hong Park}

Korean J Pain 2019;32(4):314-315

https://doi.org/10.3344/kjp.2019.32.4.314 pISSN 2005-9159 eISSN 2093-0569

Department of Anesthesiology and Pain Medicine, Daegu Wooridul Spine Hospital, Daegu, Korea

Check for updates

I would like to thank Dr. Jo for his interest and concerns regarding the transforaminal epiduroscopic laser annuloplasty (TELA) versus intradiscal radiofrequency annuloplasty (IDRA) for patients with symptomatic lumbar discogenic low back pain. I read with interest the letter to the editor regarding our paper comparing TELA and IDRA for discogenic low back pain [1] and I would like to offer the following comments and observations.

1. It is very well known that that provocative discography is a very useful diagnostic tool for confirming the pathologic level for discogenic low back pain. In cases of multilevel annular tear lesions on magnetic resonance imaging, provocative discography was performed. Occasionally, in cases where a lesion was at one level and could be clearly seen, we skipped discography. Also, disc herniation was excluded, and internal disc disruption was included in our study.

2. TELA and percutaneous endoscopic lumbar discectomy (PELD) are completely different. The main focus of PELD is the removal or decompression of the herniated disc. On the other hand, TELA refers to equipment that is used to perform an annuloplasty. A TELA working sheath cannot be inserted into the disc to observe its interior like an endoscope. The intradiscal procedure (granu- lation tissue removal) of TELA is performed under the Carm. The PELD working sheath is placed half intradiscally and half epidurally. Both the intradiscal and extradiscal procedure are fully performed under endoscopic guidance. In addition, TELA uses a small working channel (outer diameter, $3.5 \mathrm{~mm}$ ) compared with the PELD working sheath (more than $5 \mathrm{~mm}$ ). Studies using percutaneous endoscopic annuloplasty (modified PELD) have been published $[2,3]$. This procedure is performed on the disc. A comparative study of the two procedure (TELA vs. PELD) is needed to examine complications, efficacy etc.

3. Normally, IDRA is performed under the C-arm. However, in our hospital, we have a LASE ${ }^{\circledR}$ kit (Clarus Medical LLC, Minneapolis, MN). So, we performed it under the Carm and LASE $^{\circledR}$ kit. Sometimes, we have used the epiduroscope.

4. The terminology is believed to require further discussion.

\section{CONFLICT OF INTEREST}

No potential conflict of interest relevant to this article was reported. (c) This is an open-access article distributed under the terms of the Creative Commons Attribution Non-Commercial License (http://creativecommons.org/licenses/by-nc/4.0/), which permits unrestricted non-commercial use, distribution, and reproduction in any medium, provided the original work is properly cited.

(c) The Korean Pain Society, 2019
Author contributions: Chan Hong Park: Writing/manuscript preparation. 